in his steps, will widen into a broad highway. Ehrlich was honoured by almost every university. $\mathrm{He}$ was Croonian lecturer of the Royal Society, and joint recipient with Metchnikoff of the Nobel prize, and his genial and striking personality was well known to British bacteriologists. In 1897 he was created Geheimrath, and in I9II Wirklicher Geheimrath.

In the present strife of nations, we British will be the first to recognise that in the death of Paul Ehrlich a great man, worthy to be ranked with Pasteur, Lister, and Koch in his particular line, has passed away.

\section{FREDERICK VICTOR DICKINS, C.B.}

WHEN it became known to the friends of F. V. Dickins only a few days ago that a serious surgical operation had been suddenly called for, they sadly, recognised that the end was probably not far off. Heart failure and the weight of over seventy-seven years closed his life on Monday, August 16.

Dickins was a remarkable man and had enjoyed a singularly varied and interesting life. Medicine first attracted him, and after graduating (r86r) M.B. and B.Sc. in the University of London, he served for five years in the Navy between China and Japan. Then he took up law, and having been called to the bar in 1870 he practised in Yokohama for many years, and at this time began to give increasing attention to those Oriental studies which occupied him to the end of his life. In $\mathrm{I} 882$ he became Assistant Registrar to the University of London, the late Arthur Milman being then Registrar. It was in this capacity that he became known to the large circle of eminent men connected with the university, and especially the examiners. Soon after his appointment the practical examinations of the university were considerably amplified in scope, and examinations in practical physics were introduced for the first time. It is not too much to say that the successful conduct of these examinations at the outset was largely due to the energy of the assistant registrar, who not only obtained the necessary apparatus, but set up much of it with his own hands when required for the use of the examiners. A technical assistant for this business was employed later. He succeeded Milman as registrar in 1896 .

Dickins read widely and was familiar with the chief advances in physical and natural science, in which he took great interest. But his speciality was Japanese and, to a less extent, Chinese language and literature. After retiring from the registrarship in rgor his leisure was therefore naturally occupied with his favourite studies, and we owe to his pen the two volumes of "Primitive and Medieval Japanese Texts," published by the Clarendon Press in 1906, and the translation of the charming Japanese "Story of a Hida Craftsman" in I9I2, besides other works.

Dickins was a member of the Athenæum, but owing to failing health and distance, he retired from the club two years ago.

\section{NOTES.}

THe Royal Society is compiling a register of scientific and technical men in Great Britain and Ireland, who are willing to give their services in connection with the war. The register will be classified into subjects, and will ultimately constitute a large panel of men of standing, whose services will be available whenever any Government department or similar authority requires specialist assistance. The register is being co-ordinated with those independently compiled by other societies and institutions, but the Royal Society would be glad to have applications for forms from such members of the staffs of colleges and technical institutions as have not yet been registered by any society. The Royal Society is also drawing up, with the co-operation of the principal societies and institutions, a list of scientific and technical men actually on active service in His 'Majesty's forces. Any names, with rank and unit, for this list will be gratefully received by the secretaries at Burlington House, Piccadilly, W.

We learn that Mr. M. T. Dawe, formerly a member of the gardening staff of the Royal Botanic Gardens, Kew, sometime Superintendent of the Botanical and Forestry Department, Uganda, and lately Director of Agriculture, British East Africa, has been appointed Agricultural Adviser to the Government of Colombia.

THe Chilean war vessel General Baquedano, which has recently returned from Easter Island, has brought news of the Easter Island Expedition of Mr. and Mrs. Scoresby Routledge up to June 8 , at which date the expedition had been fourteen months in residence, during which time a careful survey had been made of the existing antiquities and such ethnographical information collected as is still available.

THE. Hutchinson medal for research, of the London School of Economics and Political Science, has been awarded to Mr. R. C. Mills for his thesis on "The Colonisation of Australia, $1829-1842$ : the Wakefield Experiment in Empire Building," and the Gladstone Memorial prize to Mr. C. M. Jones.

WE regret to hear that Capt. W. E. G. Atkinson, son of the late Prof. Atkinson, of the Staff College, Camberley, was killed at the Dardanelles on August 6. Capt. Atkinson was educated first at Clifton College and afterwards at the Wye Agricultural College, where he had a very successful career. In 1902 he left Wye and proceeded to the Rothamsted Experiment Station as a post-graduate research worker. Prior to that date there had been very few such workers at any time, and none for a number of years. Capt. Atkinson was the first of the modern contingent, which has since swelled considerably. He worked with $\mathrm{Mr}$. Hall on the problem of quality in wheat. Millers and farmers alike recognised the marked differences between varieties of wheat, somethe so-called strong wheats-giving grain of high baking quality, possessing great capacity for forming large, well-piled loaves, while, others-known as weak wheats-gave rise to squat, heavy-looking loaves, much less attractive in appearance. No satisfactory

NO. 239I, VOL. 95] 